\title{
The Impact of Audit Committee, Firm Size, Profitability, and Leverage on Income Smoothing
}

\author{
Veronica Indrawan ${ }^{1}$, Sukrisno Agoes ${ }^{1}$, Hisar Pangaribuan ${ }^{\star 2}$ and Oluwatoyin Muse Johnson \\ Popoola ${ }^{3}$ \\ 1 Tarumanagara University, Indonesia \\ ${ }^{2}$ Adventist University of Indonesia, Indonesia \\ 3 Tunku Puteri Intan Safinaz School of Accountancy, Universiti Utara Malaysia
}

\begin{abstract}
The objective of this study is to examine the impact of the audit committee, firm size, profitability, and leverage on income smoothing in manufacturing companies listed in Indonesia stock exchange for the period of 2013-2015. Regression statistics are employed to analyse the secondary source of data collected from the annual report of the companies. Measurement of income smoothing is proxied by discretionary accruals. The results of the study reveal that the firm size has a direct positive influence on income smoothing in the listed manufacturing companies in Indonesia. In essence, the more significant a firm size, the more actively performed income smoothing practices. In contrast, profitability indicates an adverse effect on income smoothing in the listed manufacturing companies. The adverse effect indicates that the higher the profit generated, the lesser the income smoothing practices performed. Similarly, leverage posits an adverse effect on income smoothing in the manufacturing sector. This indicates the smaller the risk of companies debt, the more exceptional the practice of income smoothing occurs. The audit committee size similarly shows a negative influence on income smoothing in the listed manufacturing companies. This finding indicates the larger audit committee size, the smaller practice of income smoothing. This occurs because the audit committee oversight function on financial reporting is more efficiently performed. The result of this research shows the contribution to theory, practice, and method, especially in developing countries.
\end{abstract}

Keywords: Income Smoothing, Firm Size, Profitability, Leverage, Audit Committee, Developing Countries

JEL Classification: M40, M41, M49

Paper Type: Research Paper

*Corresponding author: E-mail: pangabhsr@gmail.com 


\section{INTRODUCTION}

Financial statements are objected to extending financial information of the reporting entity to be used by stakeholders such as investors, loaners, and creditors in making decisions on resource provisions for the entity (Kieso et al., 2014). A prepared and reported financial statement consists of the statement of financial position, statement of profit or loss and other comprehensive income, statement of changes in equity, cash flow statement, notes to the financial statements - an integral part of the financial statements (Kartikahadi et al., 2012). Income is an indicator considered by investors in making investment decisions. The income statement is a summary of a company's business activities that arise from business activities and other activities (Fraser \& Ormiston, 2007). These include operating activities, financing activities, and investment activities. An entity makes efforts to increase the quality of earnings in preparing financial statements. The total earnings can be manipulated easily; therefore, the quality of profit should be analysed thoroughly. Focusing on the quality of earnings is also essential. Thus, the investors can be specific on the sustainability of business operations and accounting assumptions (Larrabee \& Voss, 2012).

The quality of earnings stimulates management to manipulate profit to influence the outlook of external parties. Literature has revealed that companies with stable profits indicate lower risks, and therefore, attract more investors (Akhoondnejad et al., 2013). Income smoothing practices are one of the general approaches to creative accounting (Saeidi, 2012). There are two forms of income smoothing: (1) The efforts to increase the company's report of earnings, with aiming to make the company's performance and management to look better; (2) The efforts to decrease the company's report of earnings, with aiming to reduce the company's tax obligation (Rezazadeh et al., 2014). Income smoothing is the use of managerial discretion over (within GAAP) accounting choices, earnings reporting choices, and real economic decisions to influence how underlying economic events are reflected in one or more measures of earnings (Walker, 2013).

Income smoothing is closely related to earnings management since both are patterned to the agency theory approach. Bora and Saha (2016) defined income smoothing as a kind of intentional act committed by managers using special tools in accountancy for lowering profit fluctuations. The theory states that profit management is influenced by the conflicts of interest between management as an agent and the owner, occurring when both attempt to attain prosperity (Masodah, 2007). Indonesia, among Asian countries, with a high level of income smoothing practice is positioned after Thailand and Korea (Shen \& Chih, 2007). The practice of income smoothing can be influenced by several factors, such as firm size, profitability, leverage, and non-financial factors namely good corporate governance mechanism in a proxy audit committee.

Income smoothing might be beneficial when it improves the informativeness of earnings and allows the prediction of future earnings. This occurs when managers exert their best efforts and try to reduce the current high earnings numbers if they expect a decrease in future earnings and vice versa. In this sense, income smoothing makes future earnings more predictable to shareholders especially under uncontrollable conditions, that is, changes in accounting standards (Diri, 2018). Instead, pernicious smoothing occurs when management opportunistically reports different earnings from those that are already known to them to hide the current bad news. Such activity results in worse earnings in the future when firm performance does not improve; and thus takes the shape of current income maximisation and subsequent income minimisation (Marciukaityte \& Park 2009). Scholars have adduced many reasons for income smoothing practice. The first impression of most accountants is that income smoothing is a bad thing. However, the evidence indicates that many firms choose to engage in smoothing as part of a long-term equilibrium 
reporting strategy and that companies benefit from this with a less volatile share price. (Walker, 2013).

Firm size is a variable that is measured by the total asset within the company. There is a higher tendency for large companies to avoid earning fluctuations because it will reduce the investment risks to investors and creditors. It can be said that large companies have a massive impact on the practice of income smoothing (Akhoondnejad et al., 2013).

The larger the company, the higher the financial risks that must be faced by the company (Alexandri \& Anjani, 2014). Large firms are predicted to tend to make income smoothing, as a drastic increase in profit will lead to increased corporate taxes. On the contrary, a drastic decline in profit will give the impression of a crisis within the company (Fiscal \& Steviany, 2015). Mansor et al. (2013) study discovered that smaller sized companies involved in income smoothing activities because their actions would perhaps not be scrutinised.

Profitability is an important measurement to assess the company's strength. Profitability ratio commonly used is the return on assets (ROA). ROA measures the effectiveness of the company in generating profit by optimising assets (Alexandri \& Anjani, 2014). Similarly, profitability reflects the overall effectiveness of management as represented by returns derived from sales and investments (David, 2013). Companies with low-level profitability will be motivated to perform income smoothing to influence the investors' outlook. Profitability is a measurement adopted by investors to assess whether a company is healthy or otherwise, which can influence future investment decision making. Income smoothing is often employed to make the company looks more stable. Whereas, controlled earnings are expected to show that the company has good performance, even though its profitability is not too high (Oviani et al., 2014). In addition, Mansor et al. (2013) argued in their study that the larger the companies' profitability, the lower is their participation in income smoothing. Research conducted by Alexandri and Anjani (2014) shows that profitability has a significant influence on income smoothing.

Leverage demonstrates the efficiency in utilising equity to anticipate debt. In essence, the company's ability to meet all its obligations (Subramanyam, 2014). The higher the leverage presupposes a substantial increase in debt compared to capital. The resultant effect increased risk to investors and motivate the management to perform income smoothing. Companies that are unable to pay off their debt or high level of debt tend to make income smoothing in order to prepare stable profit when negotiating for debt and getting new funds because of difficulty in finding a loan (Hidayat et al., 2016). However, if the debt is used to finance the assets is high; the risk associated with by the owner capital will also be higher. With the assumption that investors and creditors will avoid to invest or lend to companies so that substantial leverage ratio will cause investors to invest in the company will decrease. Because such conditions would lead to management's desire to practice income smoothing to attract investors and creditors (Sherlita \& Kurniawan, 2013).

Alexandri and Anjani (2014) findings showed that the leverage has a positive and substantial impact on income smoothing. The audit committee has an important role to ensure the quality of the financial reports. In this study, the audit committee is part of nonfinancial factors. The audit committee task to oversee the financial reporting process as well as to observe the internal control will increase the quality of the financial report and influence the practice of income smoothing (Uwuigbe et al., 2012). The audit committee is the final supervisor of financial reporting; it is its job to reduce opportunistic management of earnings through different means and methods (Ebrahimi \& Seyedi, 2008). Therefore, the audit committee is often regarded as the solution to ensure quality financial reporting (Yang et al., 2012). According to Handayani et al. (2016) study, the presence of an audit committee gives an adverse influence on the practice of income smoothing. 
Based on the literature, it is essential to examine the influence of firm size, profitability, leverage and the audit committee on income smoothing, especially practices that occur in manufacturing companies listed in the Indonesian Stock Exchange (IDX). This study, therefore, examines the influence of firm size, profitability, leverage and audit committee on income smoothing. The results of this study are expected to provide practical benefits or contributions to investors and company management in making decisions regarding the practice of income smoothing.

\section{LITERATURE REVIEW AND HYPOTHESES DEVELOPMENT}

The standard approach that academic accountants use to study income smoothing is agency theory. Agency theory emphasis that firms operate under conditions of uncertainty and this leads to potential information asymmetries between the executives who manage the firm and external investors. Agency theory helps to explain why there exists a demand for information that can be used for contracting purposes. For example, it is not difficult to see why debt holders may demand information to show that the firm is likely to have sufficient assets to meet their claims. Similarly, owners are likely to demand information that measures the periodic performance of the management team (Walker, 2013).

An agency relationship between shareholders and managers exists because the owners do not possess adequate expertise to manage the firm by themselves; thus the stockholders employ an agent as their representative to manage the operation of the firm (Schroeder et al., 2013). The agency problem may result in information asymmetry. Information asymmetry occurs when managers have relatively more internal corporate information and know the information is relatively faster than those external parties. Under such conditions, managers may misuse the information it knows to manipulate financial reporting in an attempt to maximise its prosperity. The extreme varieties of accounting practices have made the development of a comprehensive accounting description is a difficult situation. In order to become a theory, a description must have definite values. The theory of positive accounting arose because the existing theory could not thoroughly explain the accounting practices (Schroeder et al., 2013). The positive accounting theory uses a viewpoint that a company will organise itself most efficiently to attain its objective to keep operating (Scott, 2009).

Financial reports constitute the primary medium for companies to communicate the financial information to their stakeholders (Kartikahadi et al., 2012), this is the final product of series on summarising business transaction data (Subramanyam, 2014). Financial reports are fair and structured presentations of a company's financial positions and financial performances (Ikatan Akuntan Indonesia-PSAK, 2014). Profit occurs when income is higher than current expenses. On the other hand, loss occurs when expenses are higher than income. Earnings management has a negative impact on the quality of earnings because it can distort the information contained in the financial statements. Distortion happens when the manager arranges a transaction to amend the financial statements to make a good impression (Subramanyam, 2014). Income smoothing is only one aspect of earnings management (Subramanyam, 2014). The practice of carefully timing the recognition of revenue and expenses to balance the number of reported earnings from one period to the next is called income smoothing (Belkaoui, 2004).

Income smoothing is done by managers because they expect a benefit from the actions taken. There are several motivations for doing income smoothing. The first motive is to increase the investor's confidence in the future situation of the company and to improve their ability to predict future cash flows. The second motive is the bonus plan gained especially if the bonus or compensation is related to steady income growth. The third motive is to reduce the perceived risk of the company and further reduce the cost of 
the company's capital. The fourth motive is to reduce corporate tax expense (Obaidat, 2017).

Management may also use income smoothing to positively influence the share prices and reduce the volatility of manufacturing companies. However, the market responds negatively to the lower quality of information when income smoothing is used opportunistically, and thus, it discounts the market to end up in more volatile share prices. In this sense, the investors demonstrate a sophisticated response to income smoothing by incorporating perceptions about the risk of the different management activities when determining shares' values (Markarian \& Gill-de-Albornoz, 2012). Also, executives are more inclined to use income smoothing because it involves lower risk and tends to use aggressive smoothing strategies under the pressure of meeting income targets (Diri, 2018). Income smoothing is another way of management discretion, which gives a chance for managers to decrease the volatility of their earnings and, therefore, influences the stakeholders' risk perceptions (Walker, 2013)

\subsection{The Influence of Firm Size on Income Smoothing in listed manufacturing companies}

Firm size is a scale to classify the size of a company through a variety of ways, including total assets, log size, the value of the stock market and so forth (Alexandri \& Anjani, 2014). This study uses the total asset as a proxy for company size. Information on significant firms usually is more publicly available and could be obtained with lower costs than information on small firms. Because larger firms are more easily scrutinised by investors or regulators than smaller firms, the former type is expected to engage in less opportunistic income management than the latter (Siregar \& Utama, 2008). Akhoondnejad et al. (2013) study state that income smoothing is influenced by the size of the firm. The study of Bora and Saha (2016) investigated the income smoothing practices in India and the factors that would impact income smoothing. The study concluded that income smoothing practices were present at a lower level among firms and further stated that the small size firms smoothe income more than large firms. The firm size significantly impacts on income smoothing practice (Parijan, 2013). Similar findings argued that the firm size has a significant and positive influence on income smoothing (Lassaad, 2013; Shen \& Chih, 2007), and firm size has a positive impact on income smoothing practice (Fiscal \& Steviany, 2015). In a contrast study by Supriyanto et al. (2016), the results revealed that firm size does not have a significant influence on income smoothing. Another study stated that firm size has a significant negative influence on income smoothing (Alexandri \& Anjani, 2014). Therefore, large companies are highly motivated to perform income smoothing. Hence, the hypothesis is formulated as follows:

$\mathrm{H}_{1}$ : Firm size significantly influences income smoothing in listed Indonesian manufacturing companies

\subsection{The Influence of Profitability on Income Smoothing in listed manufacturing companies}

Profitability ratio shows the company's ability to generate earnings from its business activities (Subramanyam, 2014). Profitability portrays the effectiveness of a company to obtain earnings from the company's operations. The ratio is used to measure the effectiveness of management as a whole, which is generated by the return of sales and investment received. The higher the level of profitability, the better the performance of management in operating a company. Previous studies revealed companies with low 
profitability would tend to do more income smoothing than companies with high profitability (Oviani et al., 2014). Several ratios are used as a measurement of profitability, including the return on stockholders' equity (ROE), the return on assets (ROA), and profit margin. The study found that profitability has a positive and significant impact on income smoothing practices (Fiscal \& Steviany, 2015). On the contrary, Alexandri and Anjani (2014) found that profitability has a significant negative influence on income smoothing. Supriyanto et al. (2016) study aligned with Alexandri and Anjani (2014) position of profitability revealing a negative correlation with income smoothing. Whereas, Parijan (2013) study reported no significant impact on the relationship between profitability and income smoothing practices. Therefore, the hypothesis is formulated as follows:

$\mathrm{H}_{2}$ : Profitability significantly influences income smoothing in listed Indonesian manufacturing companies.

\subsection{The Influence of Leverage on Income Smoothing in listed manufacturing companies}

The term Total leverage or combined leverage refers to the combination of operating and financial leverages (Ross et al., 2016). The leverage ratio shows the company's ability to meet all its obligations (Subramanyam, 2014), and also measures the extent of the financial needs of companies to be financed by borrowed funds (Copeland et al., 2004). Thus, leverage is an analysis of the use of funds to the composition of debt and equity or assets and the ability to meet all its obligations. Leverage is employed to measure how much debt funds a company. The use of leverage within a company may increase a company's profit, but if something happens that does not match with expectations, then the company may experience a loss equal to the expected percentage of profit or maybe even more significant (Oviani et al., 2014). Prior studies agreed that leverage could be measured through several ratios. For example, debt to total assets ratio, debt to equity ratio, long-term debt to equity ratio and times interest earned ratio (David, 2013). Large debt resulting leverage ratio becomes large resulting in increased risk of investing in the company so that this could lead to the income smoothing (Alexandri \& Anjani, 2014). The higher level of leverage, than the funds derived from the debt, the more significant. There is a postulation that states: the higher the debt, the higher the risk that will be faced by the company. To overcome this problem, the manager tries to stabilise the company's profit to tolerate a significant amount of debt by the investors. Highly responsible firms may be less able to practice income smoothing because they are under the scrutiny of lenders (Abed et al., 2012). Alexandri and Anjani (2014) found that leverage has a significant positive influence on the practice of income smoothing. Financial leverage positively affects income smoothing practices as reported by Fiscal and Steviany (2015). In contradiction to the previous findings, Parijan (2013) argued that financial leverage has no influence income smoothing, while the study of Supriyanto et al. (2016) confirmed the adverse effect of leverage on income smoothing. Therefore, this study formulates the hypothesis as follows:

$\mathrm{H}_{3}$ : Leverage significantly influences income smoothing in listed Indonesian manufacturing companies. 


\subsection{The Influence of the Audit Committee on Income Smoothing in listed manufacturing companies}

Diri (2018) defines an audit committee as part of the board of directors and mostly dominated by non-executive directors. Audit committee plays an essential role in corporate governance as emphasised in most of the regulations (i.e., SOX). The audit committee is responsible for assisting the board and encouraging the establishment of an adequate internal control structure to improve the transparency and quality of financial reports. The audit committee aims to protect the interests of shareholders by conducting the independent and objective assessment, monitoring and inspection of various measures and policies pursued by the company. Another responsibility of the audit committee is reviewing the scope and accuracy of external audits (Agoes \& Ardana, 2011). The audit committee consists of at least one independent board commissioner and at least two members other than the issuer or public company according to Forum for Corporate Governance in Indonesia (FCGI, 2001). The audit committee becomes the monitoring committee with objectives including securing the needs of shareholders and other interested parties and efficiently working (Ghillyer, 2014). However, different attributes of the audit committee contribute to determining income management behaviour. The independence of the committee's members, their financial and governance expertise, and the higher frequency of meetings contribute to mitigating earnings management (Diri, 2018). Prior literature confirms the existence of an audit committee negatively influences the practice of income smoothing (Handayani et al., 2016). However, the study by Handayani et al. (2016) is not consistent with the results of Marpaung and Latrini (2014), which indicated that the audit committee does not significantly affect income smoothing. Uwuigbe et al., (2012) also said that a large number of audit committee members did not affect the income smoothing practices in the company. Given the several inconsistencies in previous studies, the hypothesis is thus formulated:

$\mathrm{H}_{4}$ : Audit committee significantly influences income smoothing in listed Indonesian manufacturing companies.

\section{RESEARCH METHOD}

This study analyses the research objects that consist of firm size, profitability, leverage, the audit committee and income smoothing. The study employed quantitative research with a secondary source of data. The firm size, profitability and leverage data are obtained from the company's financial statements. Audit committee data is obtained from the company's annual report, while the income smoothing data is obtained by calculating the company's annual discretionary accruals, Jones modification model, based on existing records on the company's financial statements (Akhoondnejad et al., 2013).

\subsection{Population and Sample}

The population used in this study represents all the companies listed on IDX within the observation period of 2013-2015. A selected number of samples were chosen from the population to be processed in this study. The sampling technique used was purposive sampling, the samples that conform to some criteria set by the researcher (Sekaran \& Bougie, 2013) as follows:

a) Companies listed on the IDX, which are not delisting and relisting during the period 2013-2015. 
b) Companies that present financial statements data ended on December 31 and did not suffer from losses during the observation period, as well as presenting the financial statements in Indonesian Rupiah.

\subsection{Operationalisation of the Variables}

This study uses the ratio scale for all variables, with a description of the operationalisation of the variables described in Table 1.

Income smoothing is a practice used to stabilise fluctuations in earnings by transferring profit from one period to another to raise or lower the profit (Subramanyam, 2014; Belkaoui, 2004). Income smoothing in this study uses the modified model of Jones discretionary accruals measurement. Firm size is a measurement that shows the characteristics of the size of a company to perceive several categories. In this study, firm size is measured by the logarithm of the total assets of the company (Alexandri \& Anjani, 2014). Profitability is a portrayal of the effectiveness of the company to obtain a return on the company's operations by efficiently utilising the resources of the company (Subramanyam, 2014). Profitability in this study is proxied by return on equity (ROE) as a measurement.

Table 1. Operationalisation of the Variables

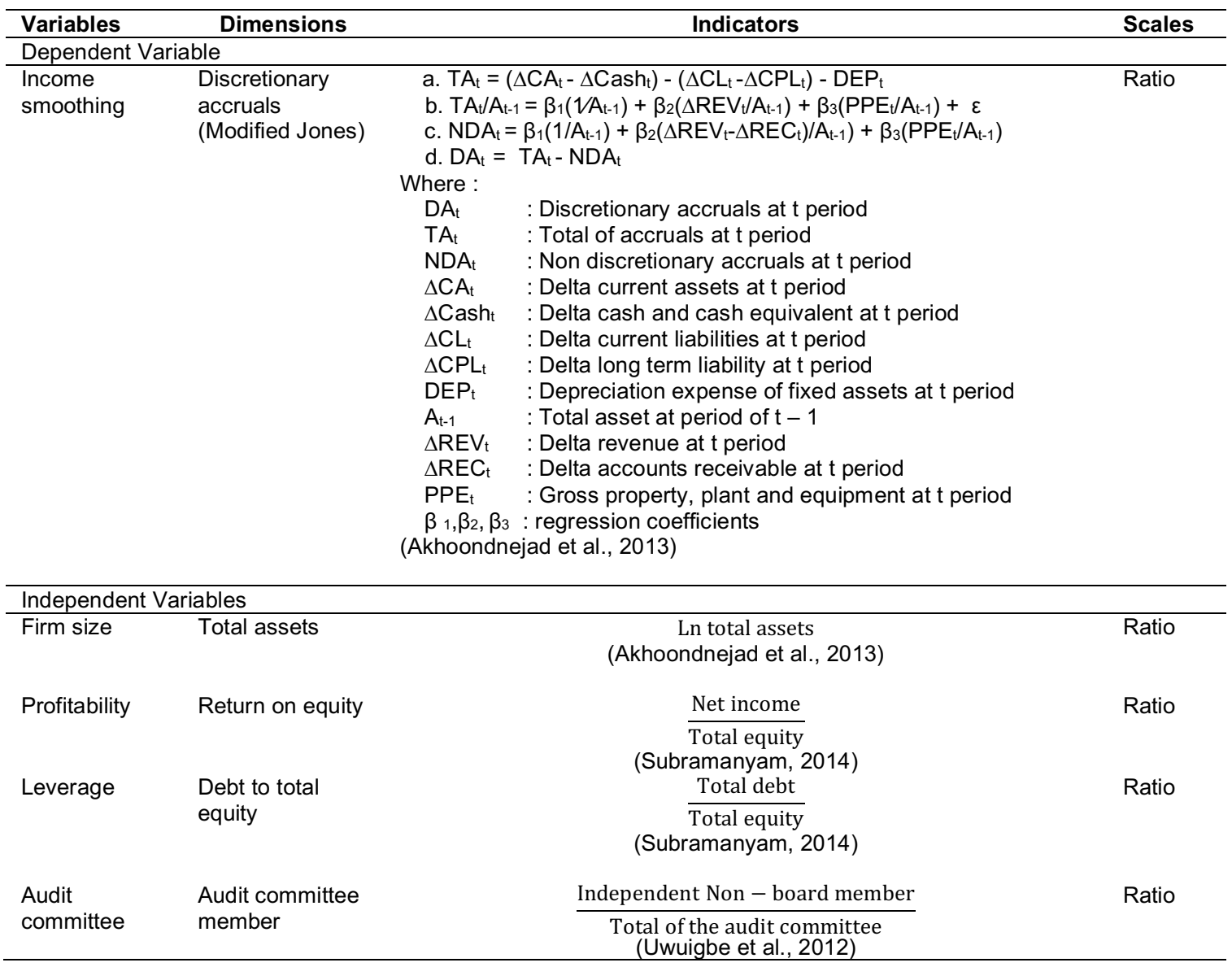


Leverage is an analysis of the use of funds by the composition of liabilities and equity or assets and the ability to pay off its obligations (Ross et al., 2016; Subramanyam, 2014). Leverage in this study adopts debt to equity ratio measurement. The audit committee is a committee in charge of overseeing the financial reporting process to provide security to shareholders and other interested parties (Agoes \& Ardana, 2011; Ghillyer, 2014). The audit committee is measured based on the number of independent non-board member of the audit committee.

\subsection{Technical Data Collection and Processing}

The data in this research are secondary data, which are provided to be processed (Sekaran \& Bougie, 2013). The research data were taken from the manufacturing company's annual report published on its website http://www.idx.co.id. The data used are from the period of 2013-2015. This study uses a significance level of $5 \%$. The software used to process variable data in this study is SPSS version 23.0 for Windows. The regression analysis was used to measure the impact of independent variables (i.e., audit committee, leverage, firm size, and profitability) on the dependent variable (i.e., income smoothing). Hypothesis testing is employed to examine: (1) correlation "r" (i.e., the strength of relationship among variables), (2) t-test (i.e., significance influence among variables), and (3) the coefficient of determination test or $\mathrm{R}^{2}$ (i.e., measure the ability of the model to explain variations on the dependent variable) as enunciated by Bartholomew et al. (2008).

\section{RESULTS AND DISCUSSION}

\subsection{Statistics Analysis}

Based on the sampling criteria, the numbers of samples obtained are 65 manufacturing companies during the periods of 2013-2015 with 195 numbers of observation. After the outlier test was done, 64 companies were obtained with 192 data used as samples for further analysis.

Table 2. Descriptive Statistics

\begin{tabular}{lcrrrr}
\hline & N & \multicolumn{1}{c}{ Minimum } & \multicolumn{1}{c}{ Maximum } & \multicolumn{1}{c}{ Mean } & \multicolumn{1}{c}{ Std. Deviation } \\
\hline Size (million IDR) & 192 & $133,782.751$ & $245,435,000.000$ & $10,322,226.980$ & $31,441,409.076$ \\
Profitability & 192 & .000626711 & .764285359 & .1443457954 & .11251209780 \\
Leverage & 192 & .074316047 & 5.972176022 & .8587640470 & .80137136980 \\
Aud_Comm. & 192 & .000000000 & .750000000 & .6130208335 & .13382768592 \\
Inc_Smooth. & 192 & -.131747398 & .618775402 & .1557953410 & .10545832490 \\
Valid N (listwise) & 192 & & & & \\
\hline
\end{tabular}

Table 2 shows the descriptive statistics of the variables of this study. The average value of firm size (in a million IDR) is 10,322,226.98. The size of the companies varies considerably as indicated by the standard deviation of $31,441,409.07$. The average value of profitability (ROE) is $14.43 \%$, with a minimum of $0.06 \%$ and maximum at $76.43 \%$, while the standard deviation for profitability is 0.1125 . The average value of leverage (debt to equity) is $85.88 \%$; indicating that nearly half of the company's capital comes from debt and standard deviation value of 0.8014 . The average value of the audit committee is $61.30 \%$ indicating $61.30 \%$ of audit committee members are independent with a range from minimum to maximum values of $0 \%$ to $75 \%$ respectively. 
The negative value on income smoothing shows that the income smoothing practice performed by management reduces the profit reported for the political cost (including minimising the tax cost) purpose, the reversal practices undertaken by management to generate better rewards and bonuses. Income smoothing practice has a mean value of 0.15579 , meaning that on average the income smoothing practice performed is by way of reporting higher income than what ought to. Management performs income reporting aims to receive bigger compensation or bonuses and to minimise the significant impression of debt risk (Obaidat, 2017). To enhance the data analysis, a regression equation model is developed for the study as follows:

$$
\text { IS }=0.123+0.004 \text { SIZE }-0.143 \text { PROFIT }-0.028 \text { LEV }-0.034 \mathrm{AC}+\varepsilon
$$

The regression model gives the interpretation that the bigger size of the company the income smoothing practice is more actively performed, the larger companies tend to do more income smoothing practice in an attempt to maintain their corporate image, including for the growth of stock prices. Management of large companies consider that the big volatility should be avoided, so they do income smoothing practices to achieve long-term performance over short-term. Regression model also shows that the companies who are experiencing downward profit tend to do more income smoothing practice to minimise wrong prejudices upon managerial and company's performance. The executive managers in a company with a small profit do not want to be considered as a fail manager in managing the company, the managers of the small profit company do income smoothing mainly for his interests, including for their performance appraisal and bonuses.

In the regression model also found that leverage and income smoothing has a negative path, the smaller company's financial risk, the more significant of income smoothing the practice performs. The companies experiencing lower leverage (lower debt to equity ratio) are motivated to do more income smoothing practice due to the smaller risks. The audit committee size and income smoothing have a negative path, the company with a decline in audit committee members tend to improved income smoothing practice due to lower supervision in the financial reporting process. On the contrary, the larger audit committee size, the smaller practice of income smoothing. This situation occurs because the audit committee oversight function on financial reporting is effectively performed.

Table 3. Multiple Linear Regression Test Results

\begin{tabular}{|c|c|c|c|c|c|}
\hline & & $\begin{array}{c}\text { Unstandardized } \\
\text { Coefficients }\end{array}$ & $\begin{array}{c}\text { Standardized } \\
\text { Coefficients }\end{array}$ & & \\
\hline Model & $B$ & Std. Error & Beta & $\mathrm{T}$ & Sig. \\
\hline (Constanta) & .123 & .154 & & .799 & .425 \\
\hline Size & .004 & .005 & .055 & .722 & .471 \\
\hline Profit & -.143 & .067 & -.152 & -2.120 & .035 \\
\hline Lev & -.028 & .008 & -.257 & -3.642 & .000 \\
\hline Ac & -.034 & .060 & -.044 & -.576 & .565 \\
\hline
\end{tabular}

\subsection{Hypotheses Testing Results}

Hypothesis testing aims to show the influence of firm size, profitability, leverage and audit committee on income smoothing with a significance level of $5 \%(\alpha=0.05)$. The result showed that the firm size has a significant value of 0.471 , higher than 0.05 and with a positive correlation between firm size and income smoothing practice. Therefore it can be concluded that Hypothesis $\mathrm{H} 1$ is rejected. This study implies that at the larger company size, there is a higher tendency of income smoothing practices that will be performed, 
although its impact is not significant. The firm size is not a significant consideration for investors in making their investment decisions. This reason accounts for its lack of influence on the management's decisions to apply income smoothing. The firm who practices income smoothing, especially for the large ones, might lose their good reputation. These research findings are in agreement with Supriyanto et al. (2016), which states that the size of the firm does not have a significant influence on income smoothing. However, the present research findings are not consistent with the studies of Akhoondnejad et al. (2013), Lassaad (2013), Alexandri and Anjani (2014), Fiscal and Steviany (2015), and Parijan (2013).

Profitability has a significant value of 0.035 ; this value is less than 0.05 with a negative correlation between profitability and income smoothing. Therefore, it can be concluded that Hypothesis $\mathrm{H} 2$ of this study is accepted, which avers that profitability has a significant impact on income smoothing. Firm's profitability is one of the factors of consideration for investors in making their investment decisions. In relation to the income-smoothing concept, a company's management stabilises profit fluctuation by moving the profit from one period to another. A particular firm increases profit when the company experiences a low profit and vice versa. The result of this study aligns with the studies by Alexandri and Anjani (2014), Fiscal and Steviany (2015), and Supriyanto et al. (2016), which argues that profitability significantly influences income smoothing. However, this study is inconsistent with the studies by Parijan (2013) and Mohebi et al. (2013) that reported negative influences on the relationship between profitability and income smoothing practices.

Leverage has a significant value of 0.000 ; this value is less than 0.05 with a negative correlation between leverage (proxied by debt to total equity) and income smoothing. It can be concluded that Hypothesis $\mathrm{H} 3$ is accepted because it reveals the significant influence of leverage on income smoothing. Leverage is another consideration for management to apply income smoothing because leverage determines the company's ability in paying off its obligations that causes an increase in risks for investors. Thus, this may motivate the management to perform income smoothing. This research result is in agreement with the studies of Alexandri and Anjani (2014), Fiscal and Steviany (2015), and Supriyanto et al. (2016), which states that financial leverage has a significant influence on income smoothing. However, the research results are not in contrast with the studies of Parijan (2013) and Mohebi et al. (2013).

The audit committee has a significant value of 0.565 . This value is greater than 0.05 with a negative correlation between the size of audit committee members and income smoothing. It can be concluded that Hypothesis $\mathrm{H} 4$ is rejected. Since the result shows that the audit committee has no significant influence on income smoothing. The audit committee is the body established by the board, and their duties are to oversee the financial reporting process, including to supervise the implementation of internal control. This committee also to oversee and to minimise management personal opportunistic actions, especially in the presentation of financial statements. This finding indicates that the larger number of independent audit committee members, the better supervisory function performed, especially in suppressing the nature of management opportunistic in the presentation of financial statements. In this situation, the financial statements will be more objectively presented and hence, better quality. The larger the number of independent audit committee members, the smaller income smoothing practices are performed. Because the audit committee's power (with a larger number of independent members) in exercising control is in a better position to discourage income smoothing. Although statistically, this finding has suggested that the impact might not be significant. This research result deviates from a study conducted by Handayani et al. (2016), which states that the independent audit committee has a significant influence on the practice of 
income smoothing. However, the findings are in agreement with the studies of Uwuigbe et al. (2012), and Marpaung and Lartini (2014).

\subsection{Coefficient of Determination Test $\left(R^{2}\right)$}

The coefficient of determination $\left(R^{2}\right)$ essentially measures the capacity of a model in explaining the variation in the dependent variable. The coefficient of determination model summary results is represented in Table 4.

Table 4. The coefficient of Determination Results $\left(R^{2}\right)$ Model Summary

\begin{tabular}{lllll}
\hline Model & $\mathbf{R}$ & $\mathbf{R}$ Square & $\begin{array}{l}\text { Adjusted } \mathbf{R} \\
\text { Square }\end{array}$ & $\begin{array}{l}\text { Std. Error of } \\
\text { the Estimate }\end{array}$ \\
\hline & $.290^{\mathrm{a}}$ & .084 & .064 & .102005801 \\
\hline
\end{tabular}

The coefficient of determination results in Table 4 shows the values of the adjusted $R^{2}$ to be $6.4 \%$. Therefore, it can be concluded that income smoothing can be explained by firm size, profitability, leverage and audit committee by $29 \%$ because of its large sample of 192. However, if it is assumed that the sample size of 192 is small, the adjusted $R$ Square is adopted (Tabachnick \& Fidell 2007). This simply means that the current study model (which includes firm size, profitability, leverage and audit committee) explains 6.4 percent of the variance in income smoothing practices, and the remaining of $93.6 \%$ accounts for other variables outside of the current study model. It could be like effective control over financial reporting process and financial report factors such as return on assets, net profit margin, debt to total assets, the value of the company, liquidity, among others. Other than financial elements, income smoothing may also be explained by non-financial variables such as corporate social responsibility and ownership.

\section{CONCLUSIONS AND RECOMMENDATIONS}

Hypothesis test result reveals the effect of firm size on income smoothing. Therefore, it can be concluded that firm size is not always taken into consideration by the investor in making investment decisions. The results of firm size show that it does not motivate the management to apply income smoothing. Profitability is one of the elements that is considered essential to investors in making investment decisions. About the incomesmoothing concept, the company's management stabilises profit fluctuation by moving the profit from one period to another. The company's management will tend to not applying the income smoothing when the company's profit is high, and vice versa.

Leverage is not highly taken into consideration by investors in making investment decision regardless of the increased risk. Thus, it does not motivate the management to apply income smoothing. When the audit committee is not independent, it limits the value of the audit committee. The ineffective monitoring of internal control resulting higher tendency of management to apply income smoothing. Through the adjusted $R^{2}$ test, it can be concluded that income smoothing can be explained by the firm size, profitability, leverage, and audit committee; the remaining can be explained by other variables other than the variables of this research. The research also concludes that income smoothing can be explained by both financial and non-financial variables.

Based on the findings of this research, it is recommended that investors must be conscious of the practice of income smoothing performed by companies as qualitative considerations in making investment decisions, especially for the companies that experience low profit and leverage. Also, the findings constitute essential input for the company's management to reconsider performing income smoothing. A company that 
performs income smoothing may reduce the trust of the investors and the company's image.

\section{REFERENCES}

Abed, S., Attar, A. \& Suwaidan, M. (2012). Corporate Governance and Earnings Management: Jordanian Evidence. International Business Research, 5(1), 216-225

Agoes, S., \& Ardana, I. Cenik. (2011). Etika Bisnis dan Profesi: Tantangan Membangun Manusia Seutuhnya. Jakarta: Salemba Empat.

Akhoondnejad, J., M. Garkaz, \& M. Shoorvazi. (2013). Political Cost Factors Affecting Income Smoothing Evidence from Tehran Stock Exchange (TSE). Interdisciplinary Journal of Contemporary Research in Business, 5(2), 341 - 350.

Alexandri, M.B., \& Anjani, W.K. (2014). Income Smoothing: Impact Factors, Evidence in Indonesia. International Journal of Small Business and Entrepreneurship Research, 3(1), 21 - 27.

Bartholomew, D.J., Steele, F., Moustaki, I. \& Galbraith, J. I. (2008). Analysis of Multivariate Social Science Data. Second Edition.

Belkaoui, Ahmed R. (2004). Accounting Theory. Fifth Edition. London: Thomson.

Bora, J \& Saha, A. (2016) Investigation on the Presence of Income Smoothing Among NSE-Listed Companies. IUP Journal of Accounting Research \& Audit Practices; Hyderabad, 15(1), 55-72.

Copeland, T.E., Weston, J. Fred \& Shastri, K. (2004). Financial theory and corporate policy. 4th Edition. Pearson.

Diri, M.E. (2018). Introduction to Earnings Management. UK: Springer International Publishing AG 2018.

David, F.R. (2013). Strategic Management. Fourteenth Edition. England: Pearson.

Ebrahimi, K. A., \& Seyedi, A. (2008). The Role of Independent Auditors in Reducing Discretionary Accruals. Accounting and Auditing Studies, 15(54), 3-16.

Fiscal, Y., \& Steviany, A. (2015). The Effect of Size Company, Profitability, Financial Leverage, and Dividend Payout Ratio on Income Smoothing in the Manufacturing Companies Listed in Indonesia Stock Exchange period 2010 - 2013. Jurnal Akuntansi dan Keuangan, 6(2).

Forum for Corporate Governance in Indonesia- FCGI. (2001). The roles of the board of commissioners and the audit committee on corporate governance; see tata kelola Perusahaan (corporate governance), Jilid II. FCGI, Jakarta Indonesia.

Fraser, L.M. \& Ormiston, A. (2007). Understanding Financial Statements. Eight edition. Pearson Prentice Hall, New Jersey.

Ghillyer, A. (2014). Business Ethics Now. Fourth Edition. New York: The McGraw Hill Education.

Hallebone, E. \& Priest, J. (2009). Business \& Management Research: Paradigms \& Practices. Hampshire, Palgrave Macmillan.

Handayani, T. B., Andini, R., \& Abrar. (2016). Pengaruh Mekanisme Corporate Governance terhadap Praktik Perataan Laba. Journal of Accounting, 2(2).

Hidayat, B.A., Sinoeraya, K. E., \& Widyaningsih, R. (2016). The Effect of Reported Comprehensive Income, Firm Size, Profitability, and Leverage on Income Smoothing.

Ikatan Akuntan Indonesia. (2014). Standar Akuntansi Keuangan Per Efektif 1 Januari 2015. Jakarta: Ikatan Akuntan Indonesia.

Kartikahadi, H., Sinaga, R.U., Syamsul, M., \& Siregar, V.S. (2012). Akuntansi Keuangan berdasarkan SAK berbasis IFRS. Jakarta: Salemba Empat.

Kieso, Donald E., Jerry J. Weygandt \& Terry D. Warfield. (2014). Intermediate Accounting: IFRS Edition. 2nd Edition. USA: John Wiley \& Sons, Inc.

Larrabee, D.T. \& Voss, J.A. (2012). Valuation Techniques. USA: John Wiley \& Sons, Inc.

Lassaad, Ben M. (2013). Communication about Environmental Information: What Drives the Effect on Income Smoothing as a proxy of Earnings Quality? Journal of Accounting and Marketing. 2(1).

Mansor, N.A., Che-Ahmad., Ahmad-Zaluki, N.A., \& Osman, A. H. (2013). Corporate Governance and Earnings Management: A Study of the Malaysian Family and Non-Family Owned. International Conference on Economics and Business Research 2013 (ICEBR 2013). 
Marciukaityte, D., \& Park, J. (2009). Market Competition and Earnings Management. Working paper, Harbert College of Business.

Markarian, G., \& Gill-de-Albornoz, B. (2012). Income Smoothing and Idiosyncratic Volatility. Working paper, IE Business School.

Marpaung, C.O., \& Latrini, Ni M. Y. (2014). Pengaruh Dewan Komisaris Independen, Komite Audit, Kualitas Audit dan Kepemilikan Manajerial pada Perataan Laba. E-Jurnal Akuntansi Universitas Udayana. 7.

Masodah. (2007). Praktik Perataan Laba Sektor Industri Perbankan dan Faktor yang mempengaruhinya. Proceding PESET. 2, A16 - A23.

Mohebi, F., Mahmoodi, M., \& Naser A. Y. Tabari. (2013). The Investigation of the Effect of FirmSpecific Accounting Variables on Income Smoothing of Companies: Evidence from Tehran Stock Exchange. World of Sciences Journal, 1(11), 109-116.

Obaidat, A. (2017). Income Smoothing Behavior at the Times of Political Crises. International Journal of Academic Research in Accounting, Finance and Management Sciences, 7(2), 113. April.

Oviani, Z., Wijaya, E.Y. \& Sjahruddin. (2014). Effect of Firm Size, Profitability, Financial Leverage and Institutional Ownership on Income Smoothing in Manufacture Company Listed on Stock Exchange in Indonesia 2009-2013. Jom FEKON, 1(2).

Parijan, Khadijeh K. (2013). Income Smoothing Practices: An Empirical Investigation of Listed Firms in Tehran Stock Exchange (TSE). Indian Streams Research Journal, 3(5), 1-5

Rezazadeh, K., Soumehsaraei, B.G. \& Gholizadeh, M. H., (2014). An Overview Income Management and Income Smoothing and Its Importance in Accounting. Kuwait Chapter of Arabian Journal of Business and Management Review. Vol. 4, No.1; September. 2014.

Ross, S.A., Westerfield, R.W. \& Jordan, B.D. (2016). Essentials of Corporate Finance. $9^{\text {th }}$ edition. Mcgraw Hill/ Irwin. The USA.

Saeidi, P. (2012). The Relationship between Income Smoothing and Income Tax and Profitability Ratios in Iran Stock Market. Asian Journal of Finance \& Accounting, 4(1), 46-51

Schroeder, Richard G., Myrtle W. Clark, Jack M. Cathey. (2013). Financial Accounting Theory and Analysis: Text and Cases. 11th Edition. USA: John Wiley \& Sons, Inc.

Scott, W. R. (2009). Financial Accounting Theory. Fifth Edition. Canada: Pearson Inc.

Sekaran, Uma, \& Bougie, R. (2013). Research Method for Business - A Skill Building Approach. 5th Edition. United Kingdom: John Wiley \& Sons Ltd.

Shen, C. H., \& Chih, H. L. (2007). Earnings Management and Corporate Governance in Asia's Emerging Markets. Journal Compilation, 15(5), Blackwell Publishing, Garsington Road, Oxford,

Sherlita, E. \& Kurniawan, P. (2013). Analysis of Factors Affecting Income Smoothing Among Listed Companies in Indonesia. Jurnal Teknologi, 64(3), 17-23.

Siregar, S.V \& Utama, S. (2008). Type of Earnings Management and the Effect of Ownership Structure, Firm Size, and Corporate-Governance Practices: Evidence from Indonesia. The International Journal of Accounting, 43(1), 1-27.

Subramanyam, K.R. (2014). Financial Statement Analysis. Eleventh Edition. New York: McGraw Hill Education.

Supriyanto, Raharjo, K., \& Andini, R. (2016). Analysis of Factors Affecting the Alignment of Income (Case Study on Automotive Companies Listed in Indonesia Stock Exchange (IDX) Period 2008 - 2013). Journal of Accounting. 2(2).

Uwuigbe, O.R., Olamide, T. F., \& Anusiem, U.F. (2012). The Effect of Audit Committee and Ownership Structure on Income Smoothing in Nigeria: A Study of Listed Banks. Research Journal of Finance and Accounting, 3(4), 26-33

Walker, M. (2013). How Far Can We Trust Earnings Numbers? What Research Tells Us about Earnings Management. Accounting and Business Research, 43(4), 445-481.

Yang, C., Tan, B.L. \& Ding, X. (2012). Corporate Governance and Income Smoothing in China. Journal of Financial Reporting and Accounting, 10(2), 120-139. 